\title{
A Road to Destruction and Self-destruction: The Same Fate of Emily and Elly
}

\author{
Pingping Yang \\ Qingdao University of Science and Technology, Qingdao, China
}

\begin{abstract}
Among Faulkner's more than one hundred short stories, "A Rose for Emily" is undoubtedly the most famous one, while "Elly" has been receiving increasing attention these years. Both of the protagonists are born in Southern aristocratic family. After their attempt to defy the conservative traditions and search for a new life becomes a failure and at the same time their dignity as Southern ladies is threatened even damaged, they choose a road to destruction with a virtual and inevitable result of self-destruction. This thesis is to illustrate the same fate of Emily and Elly from four aspects with an aim of revealing the truth that their choice of destruction and self-destruction is inevitable.
\end{abstract}

Index Terms-Emily, Elly, destruction, self-destruction

\section{INTRODUCTION}

William Faulkner (1897-1962) is admittedly a giant in the realm of American literature in the twentieth century. His short stories have not received as much attention as his monumental novels, but they are endowed with great artistic values, and more and more scholars have concentrated on them, especially on their unique narrative traits. There are also studies focusing on Faulkner's women characters in short fictions, in which Emily in "A Rose for Emily" receives more attention, a typical Southern lady poisoning her lover and keeping his corpse in her house, even sleeping with his decayed body for over forty years. Elly, the title of the story as well as the name of the protagonist, also gains increasing recognition and remarks. Both of them, born in Southern aristocratic family, are overprotected and even controlled by their parental authorities or guardians, and thereby hopelessly and resolutely choose violence and destroy their lovers when their dignity as Southern ladies, to some extent, is threatened by them.

"A Rose for Emily," a story of obsession, love, and death, is undoubtedly the most famous one among Faulkner's more than one hundred short stories. It tells of a tragedy of a screwy Southern lady Emily Grierson who is driven from stem to stern by the worldly tradition and desires to possess her lover by poisoning him and keeping his corpse in her isolated house, even sleeping with his decayed body for over forty years. The secret is not discovered until the death of Emily. This famous story that is regarded as a gothic tale inspires many people with its great artistic values. Faulkner's disordered but skillful arrangement of time plays an important role in catching readers' eyes, creating the mystic atmosphere and at last making an unfailing and thoughtful story.

"Elly" was revised from the story "Selvage" which bore Faulkner's name as well as the name of E. Oldham who was Faulkner's first lover and married him after she had divorced Cornell Franklin. According to Joseph Blotner, the story was originally hers, but she was not satisfied with her own composition, so she asked Faulkner to rewrite it (Blotner, 1977, p.42). At last it was published in 1934 and later collected in Doctor Martino and Other Stories and Collected Stories of William Faulkner. Elly, a childish and willful girl of eighteen years old, wants to get married to Paul after they are caught flirting by her grandmother, a traditional, old-fashioned and rigid old woman who is considered to be "a protector, an upholder of virtue, of past values" (Petry, 1986, p.231). Paul's repeated refusal especially after her virginity is offered as an exchange of marriage gives her a motive to fake an accident to kill her grandmother in order to prevent her from telling the truth to her parents. Eventually she drives the car down the precipice impulsively, killing both Paul and her grandmother.

This thesis is to illustrate the same fate of Emily and Elly that their creator, Faulkner, endows with the intention of revealing the conflicts between the natural expectations of young women and the cruel society that seems to destroy all of their natural needs, which lead to their inevitable destruction and self-destruction. The illustration is mainly from the following four aspects: family background, fight for life, irresponsible lover and a road to destruction and self-destruction.

\section{FAMILY BACKGROUND}

The description of the big, squarish frame house which is seated on the once most select street shows that Emily is born into a Southern well-known aristocratic family, which has remarkable social status and clings to traditional ethics. The noble parentage requires her to follow traditional rules with no doubts and behave as an elegant genteel lady, so she has to live in this house with different kinds of taboos, like a poor bird in a cage.

The house once full of nobility is now "an eyesore among eyesores" (Faulkner, 1977, p.119), which suggests that 
Grierson family has already been declining for many years. Many years ago when a deputation of the Board of Aldermen visited her for taxes, they were led to her secret house which smelled of dust and disuse, and "when they sat down, a faint dust rose sluggishly about their thighs, spinning with slow motes in the single sun-ray" (Faulkner, 1977, p.120). All these indicate that this house is inanimate and lifeless. The appearance of the hostess, Miss Emily, who "looked bloated, like a body long submerged in motionless water, and of that pallid hue" (Faulkner, 1977, p.121) really made their hair stand on end. The beginning sets suspense for the whole story and raises the readers' interest to know the mysterious house, hostess, and story.

Her father does not appear directly in the whole story, but his influence exists everywhere. "We had long thought of them as a tableau, ground, her father a spraddled silhouette in the foreground, his back to her and clutching a horsewhip, the two of them framed by the back-flung front door" (Faulkner, 1977, p.123). This is the remark of townspeople about the relationship between Emily and her father, which shows vividly the dominance of the paternalistic father over the silent daughter. The overprotective father manipulates Emily's everyday life like a despotic king and drives away all her suitors so that she is still single when she gets to be thirty. He does not think that any of the young men are quite good enough for his daughter. Her father is the only man with whom she has a close relationship, so after her father has died, she cannot admit the fact of his death and does not let people dispose of his body until "they were about to resort to law and force" (Faulkner, 1977, p.124).

Emily's domineering and overprotective father does not allow her to form a normal relationship with any men because he thinks none of them is a good match for his daughter. He is arrogant, proud, and looks down upon these young men courting his daughter. Emily is accustomed to living under this kind of severe and inappropriate paternal protection. There is not any tender and thoughtful maternal love. Therefore, she has no voice in her family and she cannot dare to strive for her own happiness and marriage. The long time of her father's control suffocates the sentiment of an ordinary girl. Her emotions are suppressed, like a dormant volcano which will not break out unless a spark appears in due conditions. Besides, the overprotection also makes the father and daughter count on each other: the father does not allow his daughter to marry any other man while the daughter also takes her father's control as a kind of protection and security, so she denies accepting his death and she can not live in the world with a feeling of being dispossessed and helpless.

"Elly" is both the title of the story and the name of the protagonist who is 18 years old. Elly is named after her grandmother-Ailanthia and lives with her parents and her grandmother in a biggish house. She almost nightly abandons herself to dallying with a different man in the veranda with screening vines and no lights. At first the targets are youths and young men of the town, but later almost anyone, "any transient in the small town whom she met by either convention or by chance, provided his appearance was decent" (Faulkner, 1977, p.208). But after that she sometimes cries silently and hopelessly and asks herself why she has done that. Elly's deaf grandmother seems to be her eyesore, because she always glares at her with sternness and blame in her eyes, although she does not say anything. Elly always has a kind of fear for her and is suffocated with silent anger. All these direct conflicts in this story are about Elly and her grandmother rather than her parents, especially her father. However, it is not difficult to find that her father's authority is the thing that manipulates her life and makes her scared when her grandmother threatens to tell the truth to her father. Her grandmother, as one of her guardians, is actually a spokeswoman for the old tradition and authority. More ridiculously, without search and fight for life and love, Elly would marry Philip, live in this lifeless Jefferson and become both a victim and an advocate of old tradition like her grandmother. At that time women should be confined to home and marriage. They are standardized and even internalized to conform to the requirement of male-headed society without any call for freedom. Miscegenation especially between white woman and black man is considered to be immoral and absolutely prohibited. The big house which Elly is confined to, to some degree, represents the "non-permissive society which is depicted as being injurious if not destructive to a number of young women in Faulkner's stories" (Skei, 1979, p.17). That intolerant society can only produce the same kind of lady without any personality or natural needs.

\section{FIGHT FOR LIFE}

People are born to fight for life. So does Emily. Her father's death is a big blow and at the same time gives her a chance to liberate her suppressed emotions. After a long grievous period she seems to be reborn and begin to get to know the world, like a bird out of cage. The sudden appearance of Homer Barron is like a spark to arouse her sense of love. He is "a big, dark, ready man, with a big voice and eyes lighter than his face" (Faulkner, 1977, p.124). He is funny and conversable, and pretty soon he becomes the focus in crowd. Such an attractive guy full of the virile fascination comes into Emily's inanimate and despairing life. Her emotion spurts out like volcano, and she falls in love with him irredeemably and appears with him in town, driving "in the yellow-wheeled buggy and the matched team of bays from the livery stable" (Faulkner, 1977, p.124). Presently townspeople learn that Emily bought man's toilet and clothing including a nightshirt, so they think they are going to be married. At that time the construction has finished and Homer has gone. They think he has gone to prepare their marriage. It seems that Homer is an oasis in the desert where she has been trudging for a long time, so she is irredeemably fascinated with this guy who makes her resuscitate. At that time, Homer replaces her father in her heart and becomes the second man that can give her warmth and sense of security. She thinks that she finally finds her soul mate, regardless of the condemnation of the gossipy townspeople, and she takes it 
for granted that she will be Homer's wife. The descriptions of "the valance curtains of faded rose color", "the rose-shaded lights" and "the delicate array of crystal and the man's toilet things backed with tarnished silver" (Faulkner, 1977, p.129) are the proof that Emily has delicately prepared their bridal chamber like a young girl awakening in love and longing for a new life. She takes it as the only chance of escaping from overall dominance and living a normal and healthy life.

Elly, in fact, has a stronger desire to fight for life than any other girls in Faulkner's short stories, including Emily. The big house which is isolated from the outside world, coupled with her grandmother's surveillance makes her feel that she is trapped in darkness with "pointlessness and emptiness of life more profound than the rage or the sense of persecution" (Faulkner, 1977, p.209). She feels confused, lost and self-pitying. "What else can I do, in this little dead, hopeless town? I'll work. I don't want to be idle. Just find me a job-anything, anywhere, so that it's so far away that I'll never have to hear the word Jefferson again" (Faulkner, 1977, p. 212). This is the long cumulative complaint in her heart. She does not want to live in this dead, hopeless Jefferson with a feeling of emptiness and despair. She wants to work to involve herself in something so that she can escape from being idle. All these show that dallying with different men is only a way of idling away her life and defying the social conventions. Actually she has sense of virginity in her mind and refuses the defloration all the time, which indicates that she is not nymphomaniacal. She just feels confused and useless because she has nothing to do every day. Elly wants desperately to marry Paul, begs him repeatedly, and even make concessions by offering her virginity as an exchange of marriage. Paul's determined refusal makes her despair and submit to the engagement to Philip. However, this is not a true submission. Three weeks before her marriage, she makes efforts to get a chance to fetch her grandmother in Mills City with Paul. She takes it as the last desperate attempt to get rid of the tedious and lifeless future. Her stubbornness and willfulness make her desire to fight for life so strong. Just like what Hans H. Skei says, Paul apparently represents Elly's only chance of breaking loose from Jefferson and stifling parental guidance, and accordingly she is unwilling to give him up (Skei, 1979, p.17).

\section{IRRESPONSIBLE LOVER}

Emily and Elly have struggled to get away from the stifling suppression and search for them a new life, but the unfortunate is that they meet wrong men, irresponsible lovers.

Homer Barron is a foreman of the construction company that comes to Jefferson to pave the sidewalks. He appears at the right moment and is supposed to be the one that can make Emily humanized after her father's death. However, Homer is a Northerner and a day laborer. In townspeople's opinion, he cannot be a good match for Miss Emily, and his humble social status makes him never qualify to marry a Southern lady. Therefore, some of the ladies say that her close relationship with Homer is a disgrace to the town and she sets young people a bad example. The meddlesome townspeople cannot just see a Southern lady corrupt the social moral environment and ruin the reputation of South, so they write to her relations in Alabama with whom her father has fallen out over the estate to treat with this matter in order to let them strictly reform Emily. Then she has two female cousins under her roof although they did not appear at her father's funeral. The ridiculousness is obvious in this part. Persuading Emily to keep the reputation as a well-bred Southern lady is more important that attending her father's funeral. It is not hard to find hypocrisy and indifference of Southern genteel family. Even though Emily becomes the center of gossips and encounters all kinds of condemnations, she still carries her head high without caring about them. However, a big shock, to both Emily and townspeople, is that Homer is not a responsible marrying man but a trustless playboy and he remarks in public that he likes men. Although some townspeople once think Emily will persuade him, the result shows that she has no capability of changing this virile creature. It is a big pity that she meets a wrong person at the right moment.

Paul de Montigny has never shown any love to Elly. He is only an irresponsible playboy and wants nothing but Elly's body, which is very obvious from the beginning. Every time when they are flirting in the screened and shadowed veranda, Paul lets out his strong longing for Elly's virginity, which he never disguises or denies. "You don't love me. I don't love you. We've never said we did" (Faulkner, 1977, p.222). The undisguised statement makes it clear that he sees through Elly and knows she does not love him and only takes him as a way of getting away from the tedious and boring life. Therefore he refuses to marry her with determination all the time regardless of her repeated begging, even after they "went into a clump of trees this morning and stayed there two hours" (Faulkner, 1977, p.218), which is an indication that Elly has already offered her virginity to Paul. In addition, Paul is a mulatto, a product of the immoral miscegenation. When Paul goes to Elly's house to visit her, her grandmother instinctively recognizes Paul as a mulatto as soon as she meets him and responses furiously. Elly sees her grandmother "without moving below the hips, start violently backward as a snake does to strike" (Faulkner, 1977, p.211). That night when Elly is dallying with Paul in a close clump of shrubbery on her lawn, she is "lost, her blood aloud with desperation and exultation and vindication too, talking inside her at the very brink of surrender loud as a voice: 'I wish she were here to see! I wish she were here to see" (Faulkner, 1977, p.211)! When she see her grandmother just stand behind them, she is anxious and even scared but she accuses her grandmother of her profligacy and thinks "she drove me to it, then prevented me at the last moment" (Faulkner, 1977, p.211). The obvious fear and resent that Elly feels towards her grandmother help her to realize that having a relationship with Paul is the best way of antagonizing her grandmother, but Paul is far from that man. 


\section{A RoAD TO DESTRUCTION AND SELF-DESTRUCTION}

Both Emily and Elly choose to destroy the man whom they can not get married to. They are forced to a road to destruction and self-destruction step by step.

Emily's tragedy is that when marriage becomes impossible, she tries hard to make Homer a prisoner of love. Her cousins' visiting is undoubtedly the last straw for her tragedy. During her cousins' staying with her, Emily bought arsenic without telling the druggist what she was going to use it for, and the druggist had his doubts about whether she bought it for rats although he wrote like that on the package. After another week her cousins leave and Homer is back three days later. At dusk one evening, people see Homer enter Emily's house, and that is the last time people see him. From that time on Emily seldom appears on the streets and her front door remains closed. Time is a good cure for extinguishing the hot gossips when the hero and heroine disappear from view, and finally everything is calm. Over forty years later, after Emily's death, people are startled by the truth that Homer does not disappear but lies dead in the bed in Emily's secret room. The secret room is supposed to be their bridal chamber which Emily has delicately prepared. Therefore, everything comes out. People finally get to know why many years ago she bought arsenic without telling the use. The strange smell of her house, the always closed front door, her incarceration in her house, and Homer's mysterious disappearance all become very clear.

The truth is that she poisons Homer secretly and resolutely. Therefore, Emily protects her dignity and reputation, and at the same time she confines her lover in her room from everlasting to everlasting, although it is only a dead body that lies in bed. The last part of the story is the most unimaginable thing. "Then we noticed that in the second pillow was the indentation of a head. One of us lifted something from it, and leaning forward, that faint and invisible dust dry and acrid in the nostrils, we saw a long stand of iron-gray hair" (Faulkner, 1977, p.218). The indentation of a head in the pillow beside Homer's corpse and a long strand of iron-gray hair are the implication that Emily even lay beside him. The rose-like bridal chamber becomes a tomb for the couple, with one of them physically dead, the other psychologically dead. She destroys the man who has damaged her dignity, reputation and longing for marriage, and at the same time she destroys herself. However, her murder and abnormal behavior of keeping a dead body do not arouse resent, while sympathy for her miserable fate is prevailing in the story.

It is obscure to readers that what happens after Homer enters Emily's house at dusk one evening. Readers get to know the result by analyzing all the facts and hints. However, the process of Elly being driven to destruction is clear, and it seems that readers are watching the tragedy happening. Elly asks, even begs Paul to marry her, and does not hesitate to exchange marriage with her virginity which Paul always desires to get. However, Paul refuses the marriage. A week later she is engaged to Philip, a promising young assistant cashier in the bank, but she does not love him and feels that she lives a dead life as if she were already dead. Two months later, she deceives her mother and drives with Paul, instead of Philip, to bring her grandmother back from her uncle in Mills City. On the way to Mills City she deliberately loses her virginity to him, but Paul still refuses to marry her very determinedly. In her uncle's house, she and her grandmother have a big quarrel over Paul's being there as a guest and the old woman refuses to put a foot in that car, and says "He shall not drive me to Jefferson. I will not put a foot in that car, and you shall not. We will go home on the train. No blood of mine shall ride with him again" (Faulkner, 1977, p. 218). In violent rage she throws out that they went into a clump of trees that morning and stayed two hours in order to infuriate her. In order to prevent her grandmother from telling her parents she has lost her virginity she attempts to fake an accident to kill her grandmother, but Paul refuses constantly. On the way back to Jefferson she begs him to marry her and is refused ruthlessly again. The conflicts are irremediable, and at last, she desperately grasps at the wheel and drives straight down the precipice, but she is by accident flung out of the car and survives.

It is Paul's final refusal to marry her that drives her to extreme insanity and makes her drive the car down the precipice. She destroys the person she desires in the process of destroying the other person who is the obstacle to what she desires. On the one hand, Elly's tragedy shows that life under the pressure of Southern aristocratic dominance is so desperate and helpless that a girl of adolescent age is forced to be a flapper, attempt to defy parental authority and eventually come to an extreme to kill her grandmother; on the other hand, it shows how useless and limited an individual's defiance of a whole society is. The endeavor to break loose from forbidding dominance and search for a new life is doomed to failure.

\section{CONCLUSION}

The similarity of Emily and Elly lies in the fact that they are entangled by their unrealizable dreams and destroy the obstacle to their destination. They are courageous to defy the old-fashioned and destructive patriarchy and attempt to dominate their own life and love. When their love and marriage fall to scattered pieces, they do not hesitate to choose violence and defend their reputation according to social rules. However, their defiance is only halfway. On the one hand, they defy Southern values and hate parental authority; on the other hand, they submit to them to some extent. Therefore, the process of self-destruction is unavoidable.

The same miserable fate endowed by Faulkner earns great sympathy for them. They can not break loose from the society they are trapped in. At the same time, Faulkner accuses the intolerant even injurious social system of harm and destruction on women and makes it clear that the struggle which is dependent on one individual has no possibility of 
success. The progress of culture and society can not be achieved in a short period, but needs cooperative fight in the long run.

\section{REFERENCES}

[1] Blotner, Joseph. (1977). Selected Letters of William Faulkner. New York: Random House, Inc.

[2] Dawling, David. (1989). William Faulkner. Houndmills: MacMillan Education Ltd.

[3] Faulkner, William. (1977). Collected Stories of William Faulkner. New York: Random House, Inc.

[4] Ferguson, James. (1991). Faulkner's Short Fiction. Knoxville: The University of Tennessee Press.

[5] Petry, Alice H. (1986). Double Murder: The Women of Faulkner's "Elly". In Fowler, Doreen \& Ann J. Abadie (Eds.), Faulkner and Women: Faulkner and Yoknapatawpha, 1985. Jackson: University Press of Mississippi, 220-234.

[6] Skei, Hans H. (1979). The Trapped Female Breaking Loose: William Faulkner's "Elly" (1934). American Studies in Scandinavia, 11, 15-24.

Pingping Yang was born in Zhucheng, China in 1980. She received her Master Degree in English Language and Literature from Wuhan University, China in 2006.

She is currently a lecturer in the School of Foreign Languages, Qingdao University of Science and Technology, Qingdao, China. Her research interests include English and American literature. 